Original Research Paper

\title{
Pengembangan Manajemen Pengolahan Sampah Menjadi Aneka Produk Yang Memiliki Nilai Ekonomis Tinggi Untuk Meningkatkan Pendapatan Masyarakat Desa Pijot
}

\author{
Embun Suryani ${ }^{1}$, L. M. Furkan ${ }^{1}$, Serifudin ${ }^{1}$, Muhdin ${ }^{1}$, M. Ali $^{2}$ \\ ${ }^{1}$ Fakultas Ekonomi dan Bisnis, Universitas Mataram, Mataram,Indonesia; \\ ${ }^{2}$ Fakultas Peternakan, Universitas Mataram, Mataram,Indonesia.
}

DOI: https://doi.org/10.29303/jpmpi.v4i2.809

Sitasi: Suryani, E., Furkan, L. M., Serifudin., Muhdin., \& Ali, M. (2021). Pengembangan Manajemen Pengolahan Sampah Menjadi Aneka Produk Yang Memiliki Nilai Ekonomis Tinggi Untuk Meningkatkan Pendapatan Masyarakat Desa Pijot. Jurnal Pengabdian Magister Pendidikan IPA, 4(2)

\section{Article history}

Received: 29 Maret 2021

Revised: 29 Mei 2021

Accepted: 25 Juni 2021

*Corresponding Author: Embun Suryani, Universitas Mataram, Mataram, Indonesia Email:

embunsuryani@unram.ac.id
Abstract: Desa Pijot memiliki potensi wisata bahari yang sangat penting, karena merupakan pintu gerbang terdekat untuk memasuki daerah-daerah wisata Pantai Pink dan 27 gili melalui wilayah perairan. Aspek negatif dari potensi wisata ini adalah sampah. Masyarakat terbiasa membuang sampah sembarangan dan umumnya masyarakat desa membuah sampah di selokan dan pematang sawah, sehingga menyebabkan tersumbatnya saluran air, yang mengakibatkan terjadinya banjir pada musim penghujan. Langkah awal yang dapat dilakukan untuk meminimalkan sampah, terutama sampah rumah tangga adalah melakukan pemilahan antara sampah organik dan sampah anorganik. Sampah organik dapat dijadikan kompos, sedangkan sampah anorganik dapat dijadikan aneka kreasi daur ulang. Namun, pengetahuan masyarakat Desa Pijot terkait manajemen pengelolaan dan pengolahan sampah masih sangat terbatas. Untuk itu, kegiatan ini bertujuan untuk mensosialisasikan manajemen pengelolaan dan pengolahan sampah menjadi berbagai produk yang bernilai ekonomis, sehingga dapat menjadi salah satu kegiatan ekonomi kreatif masyarakat untuk meningkatkan pendapatannya. Pendekatan yang digunakan dalam kegiatan ini adalah Participatory Rural Appraisal yang menekankan keterlibatan masyarakat dalam keseluruhan kegiatan mulai dari perencanaan, pelaksanaan dan evaluasi program. Masyarakat sasaran yang ingin dicapai dari kegiatan ini adalah Pokdarwis dan Kelompok PKK Desa Pijot. Hasil dari kegiatan ini adalah masyarakat sasaran mengalami peningkatan pemahaman dan ketrampilan untuk mengolah sampah organik dan sampah plastik menjadi berbagai produk yang bernilai dan memiliki nilai jual. Sampah organik diolah menjadi pupuk kompos dan pupuk cair, sedengkan sampah plastik diolah menjadi ecobrick dan berbagai produk souvenir berbahan plastik. Melalui pengolahan sampah ini dapat menciptakan lingkungan yang bersih dan mendukung Desa Pijot sebagai destinasi wisata bahari. Selain itu, dengan dilaksanakannya kegiatam PKM ini maka terjadi peningkatan dan perbaikan kemampuan dan ketrampilan masyarakat sasaran yang mendukung terjadinya peningkatan kegiatan ekonomis masyarakat. Diharapkan melalui kegiatan ini dapat menumbuhkan ide-ide kreatif, untuk mendapatkan hasil yang lebih baik dan lebih bervariasi yang kemudian dapat dijadikan modal awal untuk memulai usaha.

Keywords: Sampah Organik; Sampah Plastik; Pupuk Cair; Pupuk Kompos; Ecobrick; Souveni 


\section{Pendahuluan}

$D^{\text {est }}$ esa Pijot merupakan pintu gerbang terdekat untuk memasuki daerah-daerah wisata Pantai Pink dan 27 gili melalui wilayah perairan. Sebelum para wisatawan berangkat menuju pulau-pulau kecil, mereka akan membeli aneka keperluan di Desa Pijot dan Tanjung Luar. Tempat penyeberangan pun tersedia di Desa Pijot, Desa Tanjung Luar dan Desa Ketapang Raya. Aspek negatif dari potensi wisata ini adalah sampah. Perkembangan jumlah sampah yang semakin meningkat disebabkan oleh salah satunya karena peningkatan aktivitas manusia yang belum diiringi dengan kesadaran masyarakat dalam dalam mengelola sampah.

Isu sampah sudah menjadi isu nasional yang harus segera ditangani. Undang-Undang Nomor 18 tahun 2008 tentang Pengelolaan Sampah beserta Peraturan Pemerintah Nomor 81 Tahun 2012 mengamanatkan perlunya perubahan paradigma yang mendasar dalam pengelolaan sampah yaitu dari paradigma kumpul-angkut-buang menjadi pengolahan yang bertumpu pada pengurangan sampah dan penanganan sampah. Pengurangan sampah dapat dilakukan dengan melaksanakan kegiatan pembatasan timbunan sampah, pendauran ulang dan pemanfaatan kembali sampah atau yang lebih dikenal dengan sebutan Reduce, Reuse dan Recycle (3R) melalui upaya-upaya cerdas, efisien dan terprogram. Beberapa dampak apabila sampah tidak dikelola dengan baik adalah sebagai berikut (Suwerda, 2012:6): 1) sampah dapat menjadi sumber penyakit, lingkungan menjadi kotor; 2) pembakaran sampah dapat berakibat terjadinya pencemaran udara yang dapat mengganggu kesehatan masyarakat, dan memicu terjadinya pemanasan global; 3) pembusukan sampah dapat menimbulkan bau yang tidak sedap dan berbahaya bagi kesehatan, cairan yang dikeluarkan dapat meresap ke tanah, dan dapat menimbulkan pencemaran sumur, air tanah, dan yang dibuang ke badan air akan mencemari sungai; dan 4) pembuangan sampah kesungai atau badan air dapat menimbulkan pendangkalan sungai, sehingga dapat memicu terjadinya banjir. Lebih lanjutt, Andarani dan Goto (2014) menyatakan bahwa pengelolaan sampah akan melindungi lingkungan dan membuat masyarakat bertambah sehat.

Penyelesaian masalah sampai bisa dilakukan melalui warga-warga terutama wanita (ibu-ibu) yang berada di lingkungan. Setiap rumah tangga dilibatkan dalam pengelolaan sampah, minimal dimulai dari pengelolaan sampah rumah tangganya sendiri. Peran ibu rumah tangga sangat penting dalam pengelolaan dan pengolahan sampah, terutama sampah rumah tangga. Penelitian yang dilakukan oleh Setyowati dan Mulasari (2013) menyimpulkan bahwa ada hubungan yang sangat signifikan antara tingkat pengetahuan ibu rumah tangga dengan perilaku mengelola sampah plastik. Untuk itu, sangat penting artinya mensosialisasikan manajemen pengelolaan dan pengolahan sampah pada ibu rumah tangga.

Dilain sisi, keberadaan sampah ternyata sangat berpotensi terhadap penciptaan pendapatan rumah tangga. Novianty (2013) menyimpulkan bahwa terdapat dampak yang positif terhadap kehidupan sosial ekonomi masyarakat di Kelurahan Binjai setelah adanya pembangunan Bank Sampah. Selanjutnya, Wardi (2011) juga mengatakan bahwa sampah yang dikelola dengan baik selain mendapatkan keuntungan ekonomi juga mendapatkan keuntungan sosial seperti kesehatan dan estetika lingkungan (bau dan pemandangan yang tidak sedap).

Pengolahan sampah dapat dilakukan dengan membagi sampah menjadi sampah organik dan anorganik. Pengolahan sampah organik dapat dilakukan dengan cara pembriketan, produksi gas bio, dan pelet ternak (Wahyono, 2001). Komposting juga merupakan salah satu cara mengolah sampah organic. Kompos adalah hasil penguraian parsial/tidak lengkap dari campuran bahan-bahan organik yang dapat dipercepat secara artifisial oleh populasi berbagai macam mikroba dalam kondisi lingkungan yang hangat, lembap, dan aerobik atau anaerobik (Al-Barakah, et.al, 2013). Membuat kompos adalah mengatur dan mengontrol proses alami tersebut agar kompos dapat terbentuk lebih cepat, yang meliputi membuat campuran bahan yang seimbang, pemberian air yang cukup, pengaturan aerasi, dan penambahan aktivator (http://id.wikipedia.org/wiki/Kompos).

pengomposan

Sampah anorganik yang berupa plastik yang berasal daribberbagai macam kebutuhan hidup manusia. Permasalahan yang paling utama dari plastik adalah limbah plastik yang tidak bisa terurai secara alami dan memerlukan waktu yang sangat lama untuk membersihkan sampah plastik dari muka bumi. Terlebih lagi karena penggunaan plastik hampir tidak bisa dikendalikan. Ecobrick 
dan paving block merupakan salah satu upaya kreatif untuk mengelola sampah plastik menjadi benda-benda yang berguna, mengurangi pencemaran dan racun yang ditimbulkan oleh sampah plastic (Widodo, et al. 2019; Suminto, 2017; Amran, 2015). Ecobrick adalah salah satu usaha kreatif bagi penanganan sampah plastic, yang fungsinya bukan untuk menghancurkan sampah plastik, melainkan untuk memperpanjang usia plastik-plastik tersebut dan mengolahnya menjadi sesuatu yang berguna, yang bisa dipergunakan bagi kepentingan manusia pada umumnya (Suminto, 2017). Pemanfaatan limbah plastik juga dapat dilakukan dengan mengolahnya menjadi paving block. Pemanfaatan cacahan limbah plastik polypropylene (PP) sebagai substitusi agregat dalam pembuatan paving block terbukti mampu meningkatkan nilai kuat tekan paving block (Amran, 2015).

Masyarakat Desa Pijot memiliki kebiasaan yang buruk dalam membuang sampah sembarangan, dimana umumnya masyarakat Desa Pijot membuah sampah ke selokan, pinggir jalan dan pematang sawah, sehingga menyebabkan tersumbatnya saluran air, sehingga pada musim hujan terjadi banjir. Ditambah lagi dengan terbatasnya pengetahuan dan ketrampilan masyarakat Desa Pijot untuk mengelola dan mengolah sampah lingkungannya. Bila dilihat dari luas pekarangan masyarakat Desa Pijot yang ratarata cukup luas yang dapat dijadikan tempat untuk mengelola dan mengolah sampah. Kondisi ini menunjukkan bahwa masyarakat Desa Pijot masih kurang mengoptimalkan lahan kosong untuk pengolahan sampah yang lebih baik.

Untuk itu, kegiatan pengabdian masyarakat ini bertujuan untuk mensosialisasikan dan melatih masyarakat Desa Pijot dalam mengelola dan mengolah sampah organik maupun anorganik menjadi produk yang bernilai ekonomis dengan melibatkan seluruh lapisan masyarakat. Diharapkan melalui kegiatan ini akan mendukung terbentuknya ekonomi kreatif yang berkontribusi dalam meningkatkan pendapatan masyarakat dan menciptakan lapangan kerja. Melalui kegiatan ini diharapkan akan mampu meningkatkan ketrampilan dan keberdayaan masyarakat yang berbasis ekonomi kreatif. Kelompok masyarakat yang menjadi sasaran dari kegiatan ini adalah Pokdarwis dan ibu-ibu PKK Desa Pijot.

\section{Metode}

Berdasarkan solusi atas permasalahan prioritas desa dan untuk mewujudkan ekonomi kreatif melalui pengembangan usaha pengolahan aneka produk berbahan baku sampah organik dan anorganik di Desa Pijot, maka kegiatan ini akan dilakukan melalui pendekatan Participatory Rural Appraisal (PRA) dan Community development. Kedua pendekatan ini menekankan keterlibatan masyarakat secara langsung sebagai subyek dan obyek dalam pelaksanaan keseluruhan kegiatan mulai dari perencanaan, pelaksanaan dan evaluasi kegiatan.

Sedangkan metode yang digunakan untuk melaksanakan kegiatan ini adalah Kaji Tindak Partisipatif melalui pelatihan, pembelajaran, Demonstration plot (Demplot), dan pendampingan secara berkelanjutan dan berkolaborasi dengan kelompok sasaran.

Pelaksanaan kegiatan meliputi kegiatan penguatan kelompok melalui kegiatan workshop, demplot dan pendampingan pengembangan usaha pengolahan aneka produk berbahan baku sampah organik dan anorganik. Demplot akan dilakukan pada tahap proses produksi dan pengemasan produk hingga layak dijual. Dari kegiatan ini diharapkan kelompok sasaran dapat memulai dan mengembangkan usaha pengolahan aneka produk berbahan baku sampah organik dan anorganik tersebut.

\section{Hasil dan Pembahasan}

Pengembangan wisata bahari yang dimiliki Desa Pijot memiliki hambatan yang umum terjadi di lokasi-lokasi wisata lain yaitu terkait sampah. Kebiasaan masyarakat membuang sampah sembarangan dan tidak tersedianya bak sampah mendorong masyarakat untuk membuang sampah sembarangan. Selain itu, umumnya masyarakat desa membuah sampah di selokan, sungan dan pematang sawah, sehingga menyebabkan tersumbatnya saluran air, sehingga pada musim hujan terjadi banjir. Muara sungai selalu mendapat kiriman sampah masyakarakat, hal ini juga terjadi di Muara Selayar pantai Pijot. Untuk itu, melalui kegiatan ini disarankan dan ditekankan agar Pokdarwis Desa Pijot dapat memobilisasi kelompok masyarakat untuk secara rutin melakukan bersih pantai dan Muara Selayar. Karena keberadaan sampah tersebut sangat mengganggu pengembangan destinasi wisata. Langkah awal 
yang dapat dilakukan untuk meminimalkan sampah, terutama sampah rumah tangga adalah melakukan pemilahan antara sampah organik dan sampah anorganik. Sampah organik dapat dijadikan kompos, sedangkan sampah anorganik dapat dijadikan aneka kreasi daur ulang. Gambar 1 menunjukkan kondisi pantai Pijot dengan sampahnya dan pelaksanaan minggu bersih yang dilakukan oleh Pokdarwis dan Karang Taruna Desa Pijot.
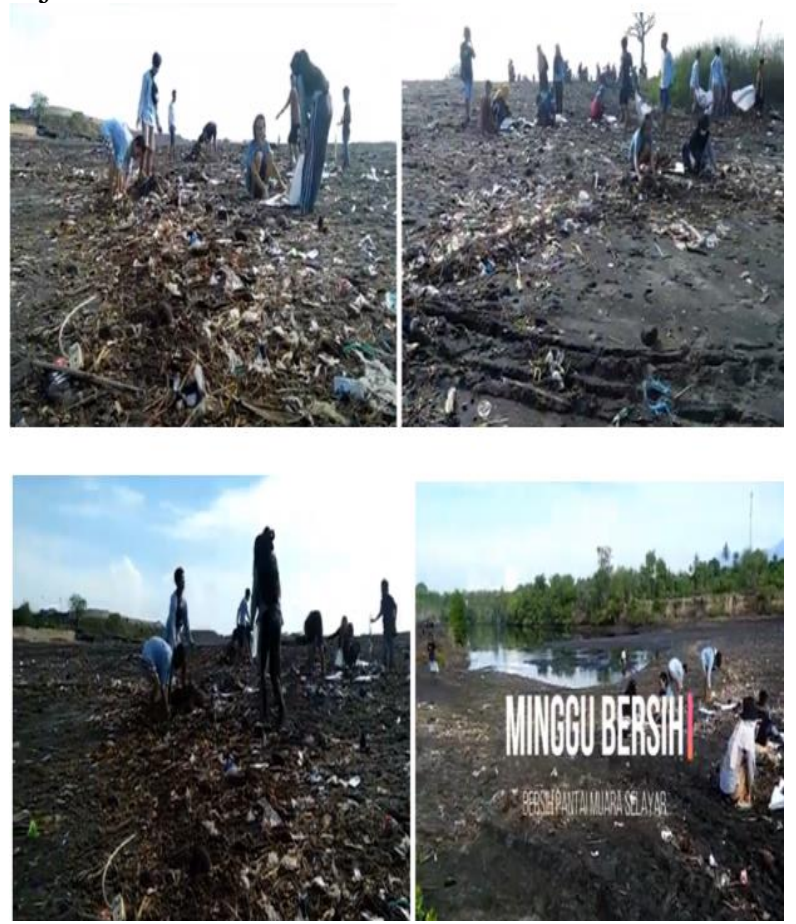

Gambar 1 Pelaksanaan Minggu Bersih Pantai Muara Selayar Desa Pijot

\section{Pengolahan sampah organik menjadi pupuk kompos}

Pada masa pandemik ini, masyarakat menjadi lebih tertarik untuk mulai berkebun di halaman rumah mereka. Hal ini menyebabkan kebutuhan akan pupuk kompos menjadi meningkat. Untuk itu kegiatan ini bertujuan untuk mensosialisasikan manajemen pengelolaan dan pengolahan sampah menjadi pupuk kompos dilakukan dengan metode keranjang Takakura, nampak seperti pada Gambar 2.
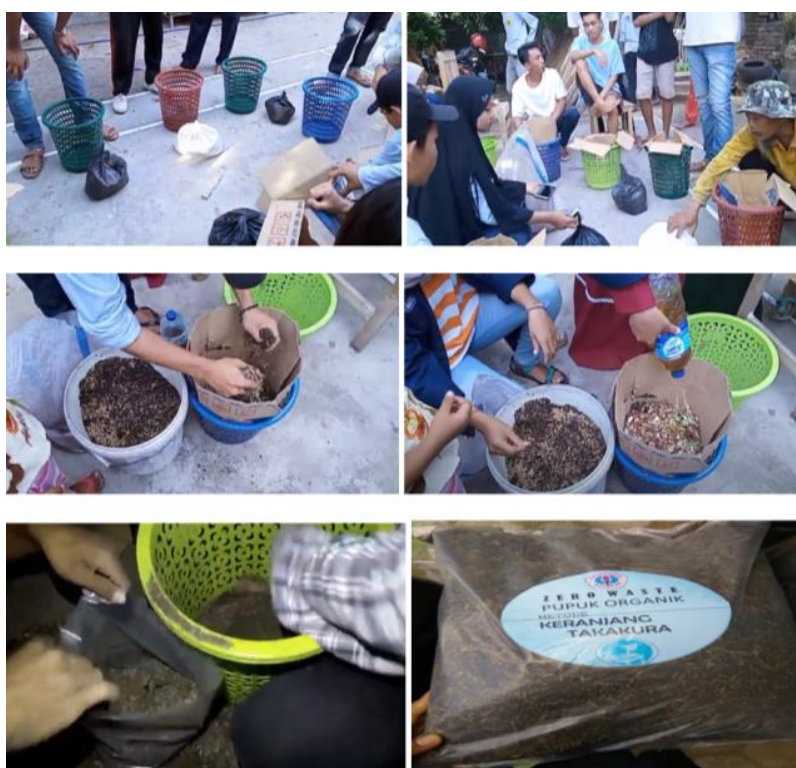

Gambar 2 Demplot Pembuatan Pupuk Kompos Dari Sampah Organik Rumah Tangga

Selanjutnya pada kegiatan ini juga dilakukan pelatihan dan demplot pembuatan pupuk kompos dari sampah organik, seperti sampah pertanian dan limbah kotoran ternak dengan proses permentasi digunakan starter yang dihasilkan di laboratorium Fak. MIPA Universitas Mataram. Proses demplot pembuatan pupuk kompos nampak pada Gambar 3 .
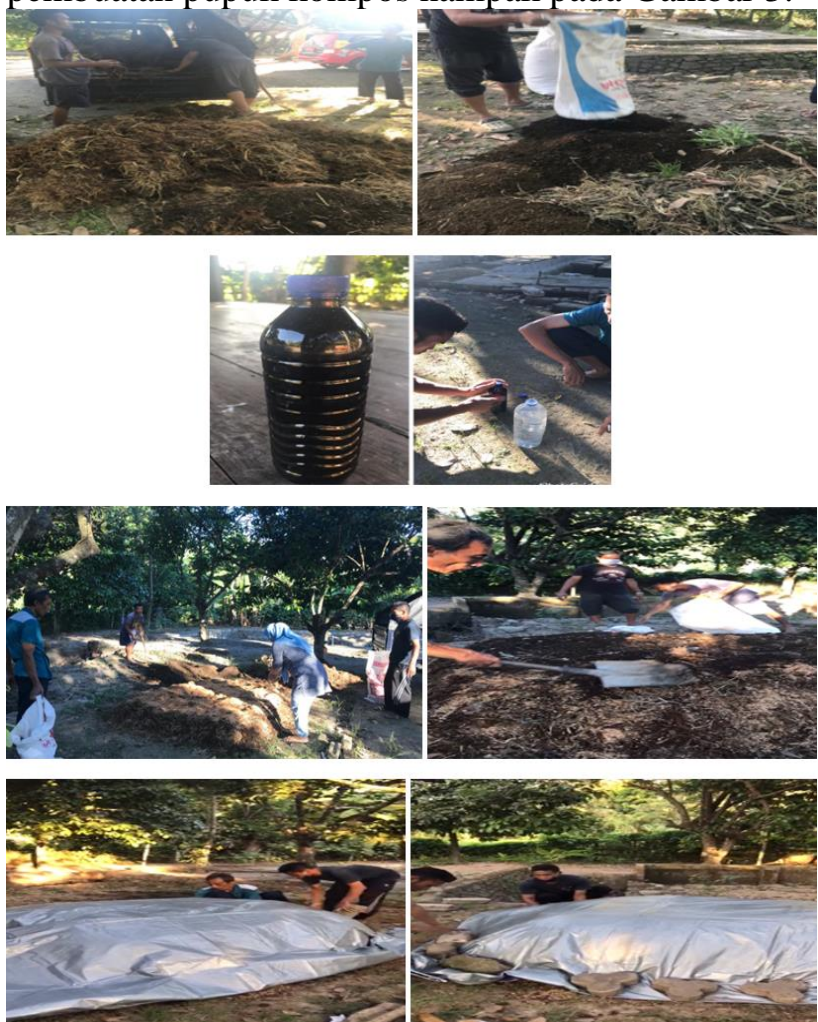

Gambar 3 Demplot pembuatan pupuk kompos 


\section{Pengolahan sampah organik menjadi pupuk cair}

Pada kegiatan ini juga dilakukan demplot pembuatan pupuk cair untuk mendukung digalakkannya usaha ketahanan pangan mandiri oleh masyarakat. Pada masa pandemic ini budidaya tanaman sayuran di pekarangan marak dilakukan oleh masyarakat. Untuk itu, produksi pupuk cair ini menjadi sangat penting, dan dapat dijadikan usaha yang dapat memberikan tambahan penghasilan bagi masyarakat. Demplot pembuatan pupuk cair bisa dilihat pada Gambar 4 berikut.

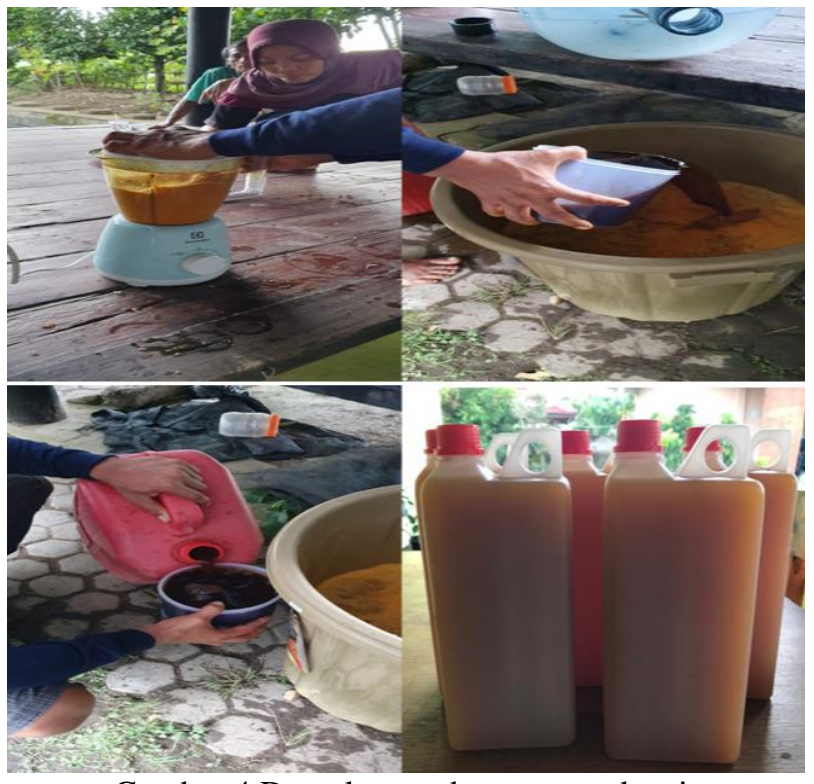

Gambar 4 Demplot pembuatan pupuk cair

\section{Pengolahan sampah plastik menjadi berbagai produk souvenir}

Selanjutnya dilakukan juga pengolahan sampah plastik dalam skala rumah tangga, yang dioleh menjadi produk-produk yang bernilai tinggi, misalnya menjadi tas, tempat gelas, dan lainnya. Sampah plastik ini juga dapat diolah menjadi ecobrick yang dapat digunakan untuk membuat berbagai produk, seperti meja, kursi, dan lainnya. Demplot pengolahan sampah plastik tersebut nampak pada Gambar 5 dan Gambar 6.
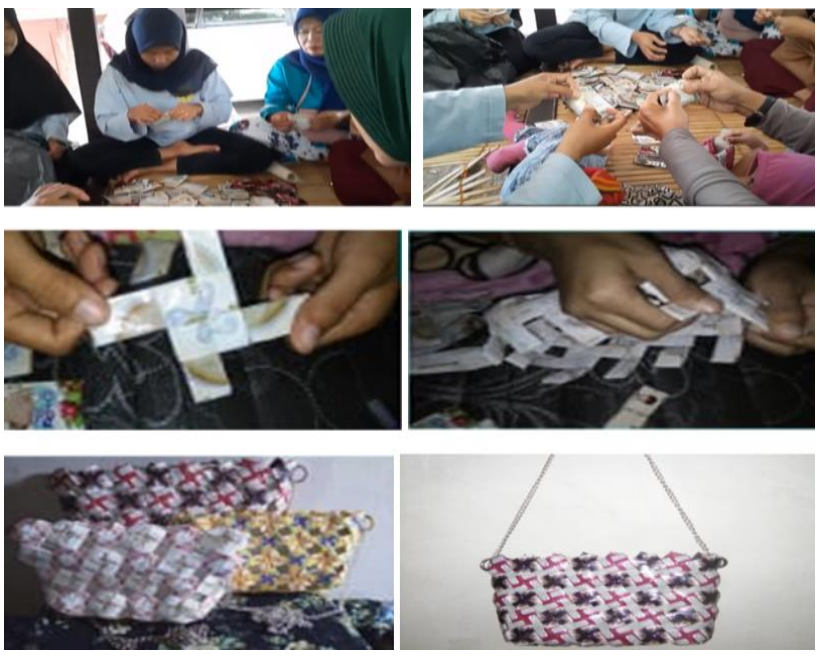

Gambar 5 Demplot pembuatan tas
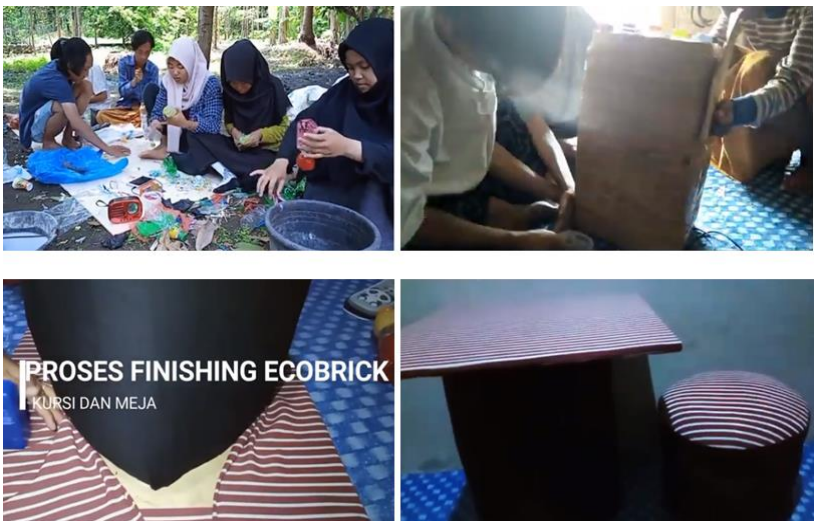

Gambar 6 Demplot pembuatan ecobrick, meja dan kursi

\section{Pendampingan Usaha}

Pendampingan pengolahan sampah organik dan plastik dilakukan di rumah peserta pelatihan. Pendampingan secara berkelanjutan dilakukan dengan tetap melakukan komunikasi dengan peserta apabila memiliki permasalahan yang ingin didiskusikan. Hal ini dilakukan sehingga bisa memberikan manfaat yang besar bagi masyarakat di Desa Pijot. Pendampingan manajemen usaha dan pembukuan sederhana juga dilakukan sebagai bekal peserta untuk memulai usahanya.

\section{Kesimpulan}

1. Evaluasi kegiatan ini menunjukkan keantusiasan peserta sangat terlihat jelas dimana hampir seluruh peserta aktif terlibat dalam proses pelatihan hingga pelatihan selesai. Peserta mampu menyelesaikan pelatihan dan demplot pengolahan sampah organik dan plastik menjadi berbagai produk bernilai ekonomis. Evaluasi 
terhadap produk sesuai dengan indikator dan tolak ukur, produk yang dihasilkan memiliki keunikan dan bermanfaat, dimana peminat dari kegiatan ini sangat banyak. Hal ini terlihat dari banyaknya peserta yang antusias.

2. Secara keseluruhan kegiatan sosialisasi dan pelatihan pengelolaan dan pengolahan sampah organik dan plastik bagi masyarakat Desa Pijot berjalan baik dan lancar. Dampak pelatihan memberikan bekal keterampilan melakukan pengolahan sampah organik dan plastik menjadi berbagai prduk yang memiliki nilai ekonomis yang tinggi. Berbagai materi yang telah diberikan, termasuk manajemen usaha, diharapkan akan membantu memudahkan proses produksi, dan diharapkan dapat berkelanjutan sebagai usaha masyarakat desa.

3. Dengan dikuasainya sejumlah ketrampilan oleh peserta pelatihan akan berdampak juga pada pertumbuhan industri kecil di desa guna peningkatan taraf ekonomi penduduk desa

\section{Saran}

1. Kepada peserta pelatihan disarankan untuk terus meningkatkan ketrampilan dan pengetahuan yang dimiliki, dan diharapkan dengan banyaknya berlatih akan menumbuhkan ide-ide kreatif, untuk mendapatkan hasil yang lebih baik dan lebih bervariasi.

2. Kepada pemerintah kecamatan dengan bekerjasama dengan institusi lain diharapkan terus berupaya memberikan bantuan kegiatan semacam ini, baik itu berupa informasi atau pelatihan ketrampilan kepada desa-desa yang memiliki potensi sumber daya alam, terutama desa-desa yang masih terbelakang dan jauh dari perkotaan.

\section{Ucapan Terima Kasih}

Penulis mengucapkan terima kasih kepada Universitas Mataram yang telah memberika dana untuk kegiatan pengabdian ini.

\section{Daftar Pustaka}

Al-Barakah, F.N., S.M. A. Radwan and R.A. Abdel-Aziz (2013). Using Biotechnology in Recycling Agricultural Waste for Sustainable Agriculture and Environmental Protection. Int. J. Curr. Microbiol. App. Sci, Vol 2(12): 446-459
Amran, Y. (2015). Pemanfaatan Limbah Plastik Untuk Bahan Tambahan Pembuatan Paving Block Sebagai Alternatif Perkerasan Pada Lahan Parkir Di Universitas Muhammadiyah Metro. Tapak, Vol. 4(2).

Andarani, P dan Naohiro, G. (2014). Potential EWaste Generated from Households in Indonesia using Material Flow Analysis. Springer Japan, Vol. 16: 306-320.

Novianty, M. (2013). Dampak Program Bank Sampah terhadap Sosial Ekonomi Masyarakat di Kelurahan Binjai, Kecamatan Medan Denai Kota Medan. Fakultas Ilmu Sosial Dan Ilmu Politik USU Medan Departemen Ilmu Kesejahteraan Sosial. Medan.

Setyowati, R dan Surahma, A.M. (2013). Pengetahuan Dan Perilaku Ibu Rumah Tangga Dalam Pengelolaan Sampah Plastik. Jurnal Kesehatan Masyarakat Nasional Vol. $7(12)$.

Suminto, S. (2017). Ecobrick: Solusi Cerdas Dan Kreatif Untuk Mengatasi Sampah Plastik. Jurnal Desain Produk (Pengetahuan Dan Perancangan Produk), Vol. 3(1): 26-34.

Suwerda, B. (2012). Bank Sampah (Kajian Teori Dan Penerapan). Yogyakarta, CV. Rihama Rohima.

Undang-Undang No 81 Tahun 2012.

Wahyono, S (2001). Pengolahan Sampah Organik dan Aspek Sanitasi. Jurnal Teknologi Lingkungan, Vol. 2(2); 113-118

Wardi, N. (2011). Pengelolaan Sampah Berbasis Sosial Budaya Upaya Mengatasi Masalah Lingkungan di Bali. Jurnal Bumi Lestari, Vol 11(1).

Widodo, S., Marleni, N. N. N., dan Firdaus, N. A. (2019). Pelatihan Pembuatan Paving Block Dan Eco-Bricks Dari Limbah Sampah Plastik Di Kampung Tulung Kota Magelang. Community Empowerment, Vol. 3(2). 